\title{
Buffered Lidocaine Hydrochloride Solution With and Without Epinephrine: Stability in Polypropylene Syringes
}

\author{
Elena Pascuet, Ronald F Donnelly, Danielle Garceau, and Régis Vaillancourt
}

\begin{abstract}
Background: Pain associated with infiltrating the skin with lidocaine can be reduced by buffering the solution with sodium bicarbonate.

Objectives: To determine the physical compatibility and chemical stability of lidocaine hydrochloride solution buffered with $8.4 \%$ sodium bicarbonate, with and without epinephrine, packaged in polypropylene syringes and stored at $5^{\circ} \mathrm{C}$ with protection from light.

Methods: Lidocaine solutions ( $1 \%$ and $2 \%)$, with and without epinephrine 1:100 000, were diluted 10:1 with $8.4 \%$ sodium bicarbonate, packaged in $3-\mathrm{mL}$ polypropylene syringes, and stored at $5^{\circ} \mathrm{C}$ (range $3{ }^{\circ} \mathrm{C}$ to $8^{\circ} \mathrm{C}$ ). On each of days $0,3,7,10,14,17,21,24$, and 28 , the contents of 3 syringes for each solution of lidocaine combined with epinephrine were collected separately in glass vials and frozen at $-70^{\circ} \mathrm{C}$ for subsequent analysis. In addition, on days $0,7,14,21$, and 28 , the contents of 3 syringes for each lidocaine solution without epinephrine were collected separately in glass vials and frozen at $-70^{\circ} \mathrm{C}$ for subsequent analysis. Chemical stability was determined with a validated, stabilityindicating high-performance liquid chromatography method. Changes in colour, clarity, and $\mathrm{pH}$ were used to determine physical compatibility of the solutions.
\end{abstract}

Results: All buffered lidocaine solutions containing epinephrine (1:100 000) retained at least $93.3 \%$ of the original concentration of epinephrine and $97.5 \%$ of the lidocaine concentration for 7 days when stored at $5^{\circ} \mathrm{C}$ with protection from light. In contrast, the epinephrinefree solutions retained at least $94.7 \%$ of the initial concentration of lidocaine for the duration of the study (28 days). All samples remained clear, colourless, and free of precipitate throughout the study, and there were no significant changes in $\mathrm{pH}$.

Conclusion: Extemporaneously prepared buffered lidocaine (1\% and $2 \%$ ) packaged in polypropylene syringes remained stable for up to 28 days when properly refrigerated with protection from light. A 7-day expiry date was established for buffered lidocaine solutions containing epinephrine, packaged in polypropylene syringes, and stored with refrigeration and protection from light.

Key words: buffered, epinephrine, high-performance liquid chromatography, lidocaine, sodium bicarbonate, stability, syringes

\section{RÉSUMÉ}

Contexte : La douleur associée aux infiltrations cutanées de lidocaïne peut être atténuée en tamponnant la solution avec du bicarbonate de sodium.

Objectifs : Déterminer la compatibilité physique et la stabilité chimique de solutions de chlorhydrate de lidocaïne tamponnées avec du bicarbonate de sodium à $8,4 \%$, avec et sans épinéphrine, etconditionnées dans des seringues de polypropylène qui ont été entreposées à une température de $5^{\circ} \mathrm{C}$, protégées de la lumière.

Méthodes : Les solutions de lidocaïne (à $1 \%$ et à $2 \%$ ), avec et sans épinéphrine à 1:100 000, ont été diluées à raison de 10:1 avec du bicarbonate de sodium à $8,4 \%$, puis conditionnées dans des seringues de polypropylène de $3 \mathrm{~mL}$, et entreposées à une température de $5{ }^{\circ} \mathrm{C}$ (fourchette de $3^{\circ} \mathrm{C}$ à $8^{\circ} \mathrm{C}$ ). Les jours $0,3,7,10,14,17,21,24$ et 28 , le contenu de trois seringues de chaque solution de lidocaïne additionnée d'épinéphrine a été recueilli séparément dans des fioles de verre et congelé à une température de $-70{ }^{\circ} \mathrm{C}$ pour analyse ultérieure. En outre, les jours $0,7,14,21$ et 28 , le contenu de 3 seringues de chaque solution de lidocaïne sans épinéphrine a été recueilli séparément dans des fioles de verre et congelé à une température de $-70{ }^{\circ} \mathrm{C}$ pour analyse ultérieure. $\mathrm{La}$ stabilité chimique a été déterminée à l'aide d'une épreuve validée par chromatographie liquide haute performance. La compatibilité physique a été évaluée en contrôlant tout changement dans la couleur, la limpidité et le $\mathrm{pH}$ des solutions.

Résultats : Toutes les solutions tamponnées de lidocaïne contenant de l'épinéphrine (1:100 000) ont conservé au moins 93,3\% de leur concentration initiale d'épinéphrine et $97,5 \%$ de leur concentration initiale de lidocaïne pendant sept jours lorsqu'elles étaient entreposées à une température de $5^{\circ} \mathrm{C}$ et protégées de la lumière. Par contraste, la concentration de lidocaïne dans les solutions sans épinéphrine est demeurée supérieure à au moins $94,7 \%$ de la valeur initiale pendant toute l'étude (28 jours). Tous les échantillons sont demeurés limpides, incolores et sans précipité tout au long de l'étude, et n'ont présenté aucun changement significatif du $\mathrm{pH}$.

Conclusion : Les préparations extemporanées de lidocaïne tamponnées (à $1 \%$ et à $2 \%$ ) conditionnées dans des seringues de polypropylène sont demeurées stables pendant une période allant jusqu’à 28 jours lorsqu'elles 
étaient adéquatement réfrigérées et protégées de la lumière. Une durée limite de conservation de sept jours a été déterminée pour les solutions de lidocaïne tamponnées contenant de l'épinéphrine, qui ont été conditionnées dans des seringues de polypropylène puis conservées au réfrigérateur et protégées de la lumière.

Mots clés : tamponnage, épinéphrine, épreuve par chromatographie liquide haute performance, lidocaïne, bicarbonate de sodium, stabilité, seringues

(Traduction par l'éditeur]

\section{INTRODUCTION}

$\mathrm{P}$ ainful treatment procedures are frequently required during visits to the emergency department, particularly for younger children who need IV therapy immediately. Among adults, painful emergency procedures include placement of central IV lines. To help ease the pain associated with such procedures, lidocaine is commonly used to infiltrate the skin because of its rapid onset of action and its long duration of sensory blockade. ${ }^{1}$ Lidocaine acts by blocking the sodium $\left(\mathrm{Na}^{+}\right)$channels in the nerve endings during both initiation and conduction of nerve impulses, which prevents the depolarization of neurons and leads to the anesthetic effects of this drug.

Buffering the $\mathrm{pH}$ of the lidocaine solution with sodium bicarbonate can reduce the pain associated with infiltration and increase its duration of action. The $\mathrm{pH}$ of plain lidocaine is about 6.3-6.4, but the addition of sodium bicarbonate converts about $50 \%$ of the drug to the free base, at a $\mathrm{pH}$ of about 8.0 (pKa 7.9). This increases the rate of penetration of the anesthetic into the nerve cells, which substantially decreases the burning sensation of infiltration and speeds up the onset of anesthesia. ${ }^{2-6}$

Although buffered lidocaine has been used in the clinical setting for several years, its long-term physical and chemical stability remains unclear. Larson and others ${ }^{4}$ examined the stability of buffered lidocaine combined with epinephrine and stored at room temperature $\left(23^{\circ} \mathrm{C}\right)$ or under refrigeration $\left(0^{\circ} \mathrm{C}\right.$ to $\left.4^{\circ} \mathrm{C}\right)$, using chromatography to measure the remaining concentrations over time. At room temperature the epinephrine concentration dropped by $27 \%$ in the first week and by $73 \%$ at 2 weeks. In contrast, the refrigerated solution remained more stable over time, and the authors concluded that buffered lidocaine with epinephrine could be stored for up to 2 weeks if refrigerated. Similar results were obtained by Stewart and others, ${ }^{7}$ who used liquid chromatography to examine the epinephrine concentration remaining in stored buffered lidocaine with epinephrine.
They found that the epinephrine concentration decreased by about $25 \%$ per week with storage at room temperature. The authors of that study suggested an expiry date of 7 days for buffered lidocaine stored at room temperature. However, it is inappropriate to extrapolate this information to buffered $1 \%$ lidocaine stored in unspecified forms of packaging. Also, flaws in the methodology of the earlier study raise questions about the validity of the assay methods that were used. The purpose of the study reported here was to conduct a physical compatibility and chemical stability study for buffered $1 \%$ and $2 \%$ lidocaine, with and without epinephrine, stored in polypropylene syringes under refrigeration with protection from light.

\section{METHODS \\ Preparation of Admixtures}

Test admixture solutions containing lidocaine 9 or 18 $\mathrm{mg} / \mathrm{mL}$ were prepared aseptically in a laminar airflow hood by diluting $46.36 \mathrm{~mL}$ of either lidocaine 1\% (AstraZeneca Canada Inc, Mississauga, Ontario; lot 99240052, expiry February 2010) or lidocaine 2\% (AstraZeneca Canada Inc; lot 99232851, expiry December 2009) with $4.64 \mathrm{~mL}$ of sodium bicarbonate 8.4\% (Hospira Healthcare Inc, Montreal, Quebec; lot 54202EV, expiry June 2009) in an empty polyvinylchloride IV bag. Multidose lidocaine vials were used. Polypropylene syringes $(3 \mathrm{~mL}$, Becton Dickinson and Company, Franklin Lakes, New Jersey) were then filled with 3-mL samples of the admixtures and stored at $5^{\circ} \mathrm{C}$ (range $4^{\circ} \mathrm{C}$ to $7^{\circ} \mathrm{C}$ ) in an unlit refrigerator.

Solutions containing both lidocaine and epinephrine were prepared, packaged, and stored in the same way as described above, using $81.82 \mathrm{~mL}$ of either lidocaine 1\% - epinephrine 1:100 000 (AstraZeneca Canada Inc; lot NL2073, expiry August 2009) or lidocaine 2\% - epinephrine 1:100 000 (AstraZeneca Canada Inc; lot NL2283, expiry February 2010) combined with $8.18 \mathrm{~mL}$ of sodium bicarbonate $8.4 \%$ (Hospira Healthcare Inc; lot 54202EV, expiry June 2009). 


\section{Sample Collection}

Immediately after preparation (day 0), the contents of 3 syringes for each of the 4 admixtures were transferred to individual glass vials and frozen at $-70^{\circ} \mathrm{C}$ in a scientific freezer (model 992, Thermo Fisher Scientific Inc, Marietta, Ohio). On days $7,14,21$, and 28, additional samples of all solutions were collected, as described previously, inspected, and then frozen in an identical manner. On days 3, 10, 17, and 24, samples of solutions containing both lidocaine and epinephrine were collected, inspected, and frozen. The study samples were analyzed for both lidocaine and epinephrine, as appropriate, once all of the samples had been collected; the final samples collected remained in the freezer for 1 month before analysis.

\section{Physical Compatibility}

On each sampling day, the same investigator (R.F.D.) inspected each sample for the appearance of particulate matter against a black background and for colour change against a white background. $\mathrm{pH}$ was determined on each sampling day using a calibrated $\mathrm{pH}$ meter with a silver-silver chloride electrode (Accumet model 25, Fisher Scientific Ltd, Nepean, Ontario). Buffers at pH 7.00 (Fisher Scientific Ltd; lot SC7134746, expiry May 31, 2009) and 10.00 (Fisher Scientific; lot SC6195146, expiry September 30, 2008) were used to calibrate the $\mathrm{pH}$ meter before each use.

\section{Chemical Stability Study High-Performance Liquid Chromatography System}

The collected samples were analyzed using validated stabilityindicating high-performance liquid chromatography (HPLC) methods. ${ }^{8,9}$ The analytical system consisted of an isocratic pump (model LC-10AT, Shimadzu Corporation, Kyoto, Japan), a photodiode array detector (model SPD-M6A, Shimadzu Corporation), and an auto-injector (model SIL-10AXL, Shimadzu Corporation) coupled with sample cooler (model S, Shimadzu Corporation) set at $4^{\circ} \mathrm{C}$. A $5-\mu \mathrm{m}, 4.6 \times 250 \mathrm{~mm} \mathrm{C}{ }_{18}$ column (Luna, Phenomenex Inc., Torrance, California; lot 410754) was used. Class-VP software (version 4.2, Shimadzu Corporation, Columbia, Maryland) was used for data collection and analysis.

The samples were analyzed for epinephrine content using the USP method, ${ }^{8}$ and the lidocaine content was determined using a modified USP method.' The modifications to the lidocaine method, intended to enable separation of the degradation products from the parent compound, were a decrease in the organic phase to $15 \%$, adjustment of the $\mathrm{pH}$ to 2.5 , and addition of an amine modifier ( $0.2 \%$ triethylamine). The flow was set at $1.5 \mathrm{~mL} / \mathrm{min}$, and peaks were monitored at $270 \mathrm{~nm}$. Fifty-microlitre samples were injected onto the column. All other conditions were as listed in the USP monographs.,
Ciprofloxacin $0.01 \mathrm{mg} / \mathrm{mL}$ (Bayer Inc, Toronto, Ontario; lot 2500LXN, expiry January 2008) was used as the internal standard in the lidocaine assay.

\section{HPLC Assay Validation}

The stability-indicating nature of both assay methods was proven by monitoring forcibly degraded samples for interfering peaks. The epinephrine method was previously validated as stability indicating. ${ }^{10}$ Three $10-\mathrm{mL}$ samples of epinephrine $(1 \mathrm{mg} / \mathrm{mL})$ were prepared. The $\mathrm{pH}$ of one sample was adjusted to 1 , the $\mathrm{pH}$ of the second sample was adjusted to 12 , and $1 \mathrm{~mL}$ of $30 \%$ hydrogen peroxide was added to $9 \mathrm{~mL}$ of the third sample. A sample obtained at time 0 was analyzed, and the degradation samples were followed over several days to identify interfering peaks. Peak purity was assessed using ultraviolet (UV) spectral overlays (200-350 nm) and multiwavelength analysis (230 and $280 \mathrm{~nm}$ ) of the parent peaks in the degradation chromatograms.

Forced degradation samples of lidocaine were created by adjusting the $\mathrm{pH}$ of $10 \mathrm{~mL}$ of a commercial solution (1\%) of lidocaine (AstraZeneca Canada Inc; lot 9923075-2, expiry November 2009) to an approximate $\mathrm{pH}$ of 1.1 with concentrated hydrochloric acid (BDH Inc, Toronto, Ontario; lot 120834-78180) or 7.6 with $1 \mathrm{~N}$ sodium hydroxide solution (Fisher Scientific Inc, Nepean, Ontario; lot SC6252970, expiry September 30,2008 ) or by adding $0.5 \mathrm{~mL}$ of $30 \%$ hydrogen peroxide (Fisher Scientific Inc; lot 073191). The $\mathrm{pH}$ of 7.6 was chosen for the alkaline degradation because the lidocaine precipitated out of solution at higher $\mathrm{pH}$ values (as indicated by cloudiness at $\mathrm{pH}$ of about 8.2 or above). All of the degradation samples were monitored 6 times over a 9-day period. Acidic and alkaline samples were incubated at $50^{\circ} \mathrm{C}$ in a hot water bath, and the oxidized sample was stored at $22^{\circ} \mathrm{C}$. A known degradation product of lidocaine, 2,6-dimethylaniline, was also tested for interference with the parent peak. The HPLC method was further validated by preparing a 5-point standard curve and by determining the precision of the method. Precision was determined by calculating the coefficient of variance for intraday comparisons (over $25 \mathrm{~h}$ ) and interday comparisons (5 separate days). The accuracy of the method was based on sample recovery, and the sensitivity was also determined. Multiwavelength (220 and $270 \mathrm{~nm}$ ) and UV spectral analysis (200-350 nm) were used to test the peak purity of the lidocaine.

\section{Stability Study}

On the day of analysis, all samples were removed from the $-70^{\circ} \mathrm{C}$ freezer and allowed to thaw to room temperature (minimum of $2 \mathrm{~h}$, maximum of $3 \mathrm{~h}$ ). The internal standard was added to the samples after further dilution with mobile phase. Once the samples had been prepared for final analysis, they were 
immediately loaded into the sample cooler until analysis. Therefore, the thawing process had little but equal effect on all samples. Samples were prepared in triplicate and assayed in duplicate after visual inspection for any precipitation that might have occurred because of freezing.

Data are reported as percentage of the initial drug concentration remaining on each study day for samples stored at $5^{\circ} \mathrm{C}$ with protection from light. The final expiry dates assigned were based on the standard acceptable pharmaceutical end point of maintaining no less than $90 \%$ of the initial drug concentration. ${ }^{11}$

\section{RESULTS}

\section{Physical Compatibility}

All admixture samples remained clear and colourless over the 28-day study period. There were no significant changes in
$\mathrm{pH}$ in any of the admixture samples under the stated storage conditions (changes of less that 0.4 for samples containing epinephrine and less than 0.12 for plain lidocaine samples).

\section{Chemical Stability}

The epinephrine degradation peaks did not interfere with either the parent compound or the internal standard peaks over the study period. The purity of all parent peaks from the degradation samples was confirmed by UV spectral overlay and multiwavelength analysis.

After 9 days of monitoring the lidocaine degradation samples, the concentration of the acidic sample had not changed much (Figure 1A) whereas the concentration of drug in the alkaline and oxidized samples had declined to $81 \%$ (Figure 1B) and $79 \%$ (Figure 1C), respectively. There were no interfering
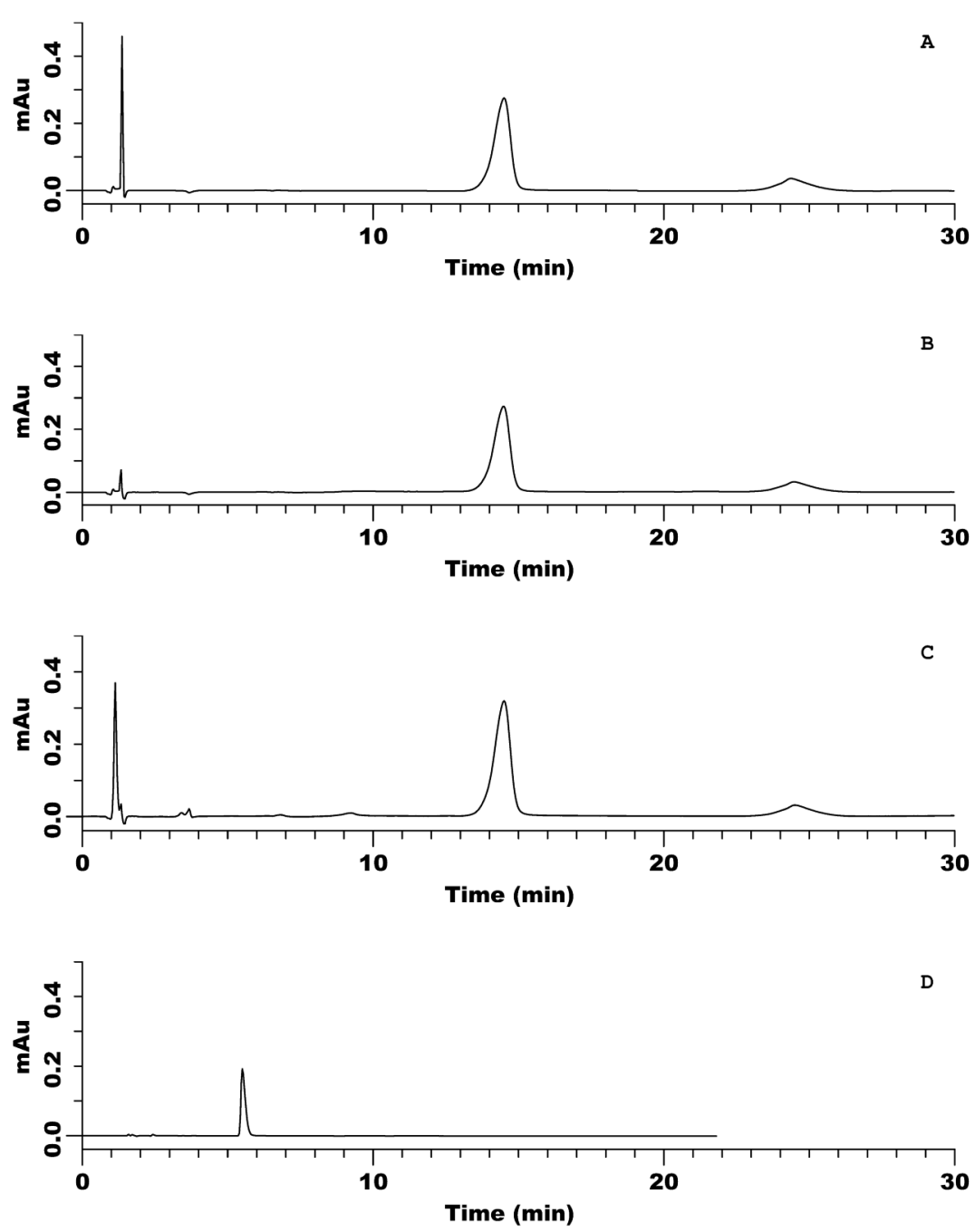

Figure 1. Sample chromatograms of lidocaine hydrochloride and its degradation products. A: Acid-degraded lidocaine after 9 days. B: Alkali-degraded lidocaine after 9 days. C: Oxidized sample after 9 days. D: A known degradation product, 2,6-dimethylaniline. Au = absorbance units full scale. 
Table 1. Stability of Buffered Lidocaine Solutions, With and Without Epinephrine, Packaged in Polypropylene Syringes and Stored at $5^{\circ} \mathrm{C}$ with Protection from Light*

Drug or Drug Combination; \% of Initial Concentration Remaining

\begin{tabular}{|c|c|c|c|c|c|c|}
\hline Study day & Epinephrine & Lidocaine $1 \%$ & Epinephrine & Lidocaine $2 \%$ & Lidocaine $1 \%$ & Lidocaine $2 \%$ \\
\hline $\begin{array}{l}\text { Mean initial } \\
\text { concentrationt }\end{array}$ & $0.009 \pm 0.0001$ & $9.5 \pm 0.07$ & $0.009 \pm 0.0001$ & $18.8+0.12$ & $8.9+0.06$ & $18.1+0.21$ \\
\hline Day 3 & $97.3 \pm 1.1$ & $\mathrm{NC}$ & $98.1 \pm 1.1$ & $\mathrm{NC}$ & $\mathrm{NC}$ & $\mathrm{NC}$ \\
\hline Day 7 & $95.9 \pm 1.7$ & $97.5 \pm 1.8$ & $93.3 \pm 0.7$ & $98.5 \pm 2.1$ & $101.1 \pm 0.7$ & $98.0 \pm 1.6$ \\
\hline Day 10 & $91.8 \pm 1.6$ & $\mathrm{NC}$ & $89.8 \pm 0.9$ & $\mathrm{NC}$ & $\mathrm{NC}$ & $\mathrm{NC}$ \\
\hline Day 14 & $84.6 \pm 1.2$ & $98.3 \pm 0.6$ & $84.3 \pm 0.7$ & $96.9 \pm 2.3$ & $101.1 \pm 0.8$ & $95.3 \pm 1.0$ \\
\hline Day 17 & $81.9 \pm 2.8$ & $\mathrm{NC}$ & $77.8 \pm 1.6$ & $\mathrm{NC}$ & $\mathrm{NC}$ & $\mathrm{NC}$ \\
\hline Day 21 & $75.3 \pm 1.7$ & $96.9 \pm 1.5$ & $74.4 \pm 1.6$ & $95.9 \pm 1.2$ & $100.6 \pm 0.6$ & $97.1 \pm 0.6$ \\
\hline Day 24 & $69.9 \pm 2.6$ & $\mathrm{NC}$ & $68.4 \pm 1.0$ & $\mathrm{NC}$ & $\mathrm{NC}$ & $\mathrm{NC}$ \\
\hline Day 28 & $61.8 \pm 1.8$ & $95.2 \pm 1.9$ & $63.9 \pm 2.5$ & $95.1 \pm 1.6$ & $98.9 \pm 1.1$ & $94.7 \pm 0.4$ \\
\hline
\end{tabular}

NC = data not collected.

*Concentrations are reported as mean percent remaining \pm standard deviation, based on 3 samples, each assayed in duplicate $(n=6)$. tInitial concentrations are reported as mean \pm standard deviation, based on 3 samples, each assayed in duplicate $(n=6)$.

peaks under any of the degradation conditions. The known degradation peak did not interfere with the parent peak (Figure 1D). Epinephrine peaks were not visible in chromatograms generated by the lidocaine assay, as they were outside the limit of detection for this method. Given the substantial difference in mobile phases between the epinephrine and lidocaine, it was expected that if the epinephrine were to be seen it would have co-eluted with the solvent front, along with the fastereluting degradation products, and would not have interfered with the lidocaine peak or internal standard.

The intraday coefficient of variance for the lidocaine method was $3.1 \%$ over a 25 -h period. The average linear coefficient for 5 separate days was 0.9996 , and the accuracy of the method, as determined by analysis of recovery samples, was $100.8 \% \pm 1.3 \%$. The interday coefficient of variance from analysis of testing on 5 separate days was $4.94 \%$, based on the daily average area ratios of the recovery samples. The sensitivity for detection of lidocaine was $2.5 \mu \mathrm{g}$.

All lidocaine peaks in the degradation samples were confirmed to be pure by multiwavelength and UV spectral analysis.

\section{Stability Study}

The results of the chemical stability study are summarized in Table 1 . Both the $1 \%$ and $2 \%$ buffered lidocaine samples were stable for up for 28 days when mixed with sodium bicarbonate $(8.4 \%)$, packaged in polypropylene syringes, and stored at $5^{\circ} \mathrm{C}$ with protection from light. In contrast, the solutions containing the lidocaine and epinephrine mixture were stable for only 7 days (based on the results for epinephrine).

\section{DISCUSSION}

Larson and others ${ }^{4}$ studied the stability of lidocaine $2 \%$ with epinephrine 1:100 000 buffered by mixing $30 \mathrm{~mL}$ of this solution with $3 \mathrm{~mL}$ of $8.4 \%(1 \mathrm{mmol} / \mathrm{mL})$ sodium bicarbonate under a sterile hood. The solution remained stable for 2 weeks when stored with refrigeration and for less than 1 week when stored at room temperature. Bartfield and others ${ }^{2}$ studied the chemical stability of plain buffered lidocaine solutions and found them to be stable for 7 days when stored at room temperature. However, both of these studies lacked proper validation of the methods and robust study design, which brings the validity of their results into question.

Several studies have evaluated clinical outcomes with buffered lidocaine., ${ }^{2,12}$ Bartfield and others ${ }^{2}$ performed concurrent testing of the 1-week-old buffered lidocaine with 24 patients and found that it caused less pain during infiltration than lidocaine alone. $\mathrm{Li}$ and Brainard ${ }^{12}$ conducted a doubleblind study comparing fresh and 2-month-old buffered lidocaine stored at room temperature. They found no difference between the 2 solutions in terms of analgesia; however, this method is not a true measure of chemical stability. A solution containing only $80 \%$ of the initial concentration may cause analgesia that is clinically indistinguishable from that produced by a freshly prepared solution, but it would not meet pharmaceutical standards.

Both epinephrine and lidocaine are more stable under acidic conditions and degrade under alkaline conditions. Under more aggressive alkaline conditions, the lidocaine amide moiety would be cleaved by the base, giving rise to 2,6-dimethylaniline. However, under mildly alkaline conditions only a minimal decrease in concentration would be expected. In this study, when the alkaline forced-degradation sample was heated for 9 days at $50^{\circ} \mathrm{C}$, the concentration declined by only $19 \%$. Oxidation of the lidocaine sample might lead to 2 new $\mathrm{N}$-oxide products. Of the 2 active ingredients, epinephrine is more sensitive to these conditions and was therefore analyzed more frequently. The starting $\mathrm{pH}$ ranged from 7.45 to 7.8 and might not have been high enough to cause cleavage of the lidocaine molecule's amide bond to create 2,6-dimethylaniline, but it 
would have been sufficient to accelerate degradation of the epinephrine. Epinephrine is also very sensitive to oxygen, and exposure to air during the compounding process would accelerate the degradation process; in contrast, lidocaine is more resistant to oxidation. Evidence of these 2 factors was seen in the results of accelerated degradation and was confirmed by the need to assign a shorter expiry date to the product containing epinephrine.

In conclusion, both $1 \%$ and $2 \%$ buffered lidocaine diluted (10:1) with $8.4 \%$ sodium bicarbonate were chemically stable for 28 days when packaged in polypropylene syringes and stored at $5^{\circ} \mathrm{C}$ with protection from light. Buffered lidocaine solutions containing epinephrine $(1: 100000)$ remained stable for only 7 days when stored in polypropylene syringes at $5^{\circ} \mathrm{C}$ with protection from light. Because these expiry dates are based on physical compatibility and chemical stability only, institutions should assign their own expiry dates on the basis of results from sterility testing.

These results are particularly important in facilitating the availability of buffered lidocaine for use when inserting IV lines, which will be helpful for younger children who require immediate placement of an IV line and for adults who require placement of a central IV line.

\section{References}

1. Kennedy RM, Luhmann JD. Pharmacological management of pain and anxiety during emergency procedures in children. Paediatr Drugs 2001;3(5):337-354.

2. Bartfield JM, Homer PJ, Ford DT, Sternklar P. Buffered lidocaine as a local anesthetic: an investigation of shelf life. Ann Emerg Med 1992;21(1): 16-19.

3. Christoph RA, Buchanan L, Begalla K, Schwartz S. Pain reduction in local anesthetic administration through $\mathrm{pH}$ buffering. Ann Emerg Med 1988;17(2):117-120.

4. Larson PO, Ragi G, Swandby M, Darcey B, Polzin G, Carey P. Stability of buffered lidocaine and epinephrine used for local anesthesia. J Dermatol Surg Oncol 1991;17(5):411-414.
5. McKay W, Morris R, Mushlin P. Sodium bicarbonate attenuates pain on skin infiltration with lidocaine, with or without epinephrine. Anesth Analg 1987;66(6):572-574.

6. Orlinsky M, Hudson C, Chan L, Deslauriers R. Pain comparison of unbuffered versus buffered lidocaine in local wound infiltration. J Emerg Med 1992;10(4):411-415.

7. Stewart JH, Cole GW, Klein JA. Neutralized lidocaine with epinephrine for local anesthesia. J Dermatol Surg Oncol 1989;15(10):1081-1083.

8. Epinephrine injection monograph. In: USP30-NF25. Rockville (MD): United States Pharmacopeial Convention; 2008. p. 2038.

9. Lidocaine hydrochloride and epinephrine injection monograph. In:USP30-NF25. Rockville (MD): United States Pharmacopeial Convention; 2008. p. 2471.

10. Donnelly R, Yen M. Epinephrine stability in plastic syringes and glass vials. Can J Hosp Pharm 1996;49(1):21-24.

11. Mollica JA, Ahuja S, Cohen J. Stability of pharmaceuticals. J Pharm Sci 1978;67(4):443-465.

12. Li J, Brainard D. Premixed buffered lidocaine retains efficacy after prolonged room temperature storage. Am J Emerg Med 2000;18(2): 235-236.

Elena Pascuet, MSc, is with the Pharmacy, Children's Hospital of Eastern Ontario, Ottawa, Ontario.

Ronald F Donnelly, MSc(Chem), BSC(Pharm), is Product Development Pharmacist, Department of Pharmaceutical Sciences, The Ottawa Hospital (Civic Campus), Ottawa, Ontario.

Danielle Garceau is a Pharmacy Technician with the Pharmacy, Children's Hospital of Eastern Ontario, Ottawa, Ontario.

Régis Vaillancourt, PharmD, is the Director of Pharmacy with the Children's Hospital of Eastern Ontario, Ottawa, Ontario.

\section{Address correspondence to:}

Ronald F Donnelly

Department of Pharmaceutical Sciences

The Ottawa Hospital

1053 Carling Avenue

Ottawa ON K1Y 4E9

e-mail: rdonnelly@ottawahospital.on.ca

\section{Acknowledgement}

This project was funded externally by the Medbuy Corporation Endowment/Bursary 2007 Fund.

\begin{tabular}{lll}
\multicolumn{3}{c}{ Advertisers ' Index } \\
\hline \multicolumn{1}{l}{ Ad Page } & Prescribing Information \\
\hline Boehringer Ingelheim / Pradax & 355 & $426-429$ \\
\hline Hospira / Epirubicin & IBC & - \\
\hline Hospira / Gemcitabine & 352 & - \\
\hline Medi-Dose / Corporate & 356 & - \\
\hline Pfizer / Fragmin & 359 & $430-434$ \\
\hline Pharmaceutical Partners of Canada / Epirubicin & IFC & - \\
\hline Pharmaceutical Partners of Canada / Website Dosing & OBC & - \\
\hline Sandoz / Corporate & 350 & -
\end{tabular}

